\title{
THE MATURATION IN VITRO OF MOUSE OOCYTES COLLECTED AT VARIOUS TIMES AFTER AN INJECTION OF PMSG
}

\author{
R. R. UNNITHAN \\ Department of Zoology, University of Rajasthan, Jaipur, Rajasthan, India
}

(Received 10th June 1974)

An injection of 5 i.u. PMSG to 21-day-old mice greatly increases the number of large follicles in the ovary but does not cause any morphological change in the oocyte (Merchant \& Chang, 1971; Cross, 1973). If an injection of HCG is given $48 \mathrm{hr}$ later, the oocytes pass rapidly through the remaining stages of meiosis and reach the second metaphase in 12 to $14 \mathrm{hr}$ (Edwards \& Gates, 1959). Oocytes which are mechanically released from the follicles and cultured in an appropriate medium without any hormonal stimulation reach second metaphase in 14 to 17 $\mathrm{hr}$ (Donahue, 1968; Cross \& Brinster, 1970). The present report deals with the fate of oocytes left in the follicles and their developmental potential at various times after an injection of PMSG.

Mouse oocytes have been matured in vitro by many workers (Edwards, 1965; Biggers, Whittingham \& Donahue, 1967; Donahue, 1968; Cross \& Brinster, 1970; Cross, 1973) and the method followed here is similar to that of Donahue (1968). Oocytes were obtained at various times (Table 1) from Swiss mice that had been injected intraperitoneally with 5 i.u. PMSG (NIAMD-PMSG-1) at 21 days of age. Each ovary was placed in a watch-glass containing medium (Krebs-Ringer salt solution containing $0.25 \mathrm{~mm}$-pyruvate, $1 \mathrm{mg} / \mathrm{ml}$ glucose and $3 \mathrm{mg} / \mathrm{ml}$ bovine serum albumin; Donahue, 1968) under oil and the follicles were punctured to release the oocytes. Before culture, a few oocytes from each animal were examined under a phase-contrast microscope for signs of nuclear maturation or other gross changes in the cytoplasm. The remaining oocytes were pooled for each time period and were washed once and cultured in drops of medium under oil at $37^{\circ} \mathrm{C}$ in $5 \% \mathrm{CO}_{2}$ in air. After $18 \mathrm{hr}$ culture, the oocytes were transferred to glass slides, compressed gently under a coverslip and examined under a phase-contrast microscope. The slides were then fixed in $10 \%$ neutral formalin overnight and stained with aceto-carmine. The stages of maturation, as shown in Table 1, were determined in accordance with the photographs of Donahue (1968).

Preliminary observations showed that no spontaneous nuclear maturation occurred up to $120 \mathrm{hr}$; all the oocytes observed had intact germinal vesicles. Spontaneous ovulation, as judged by the number of corpora lutea, was less than $1 \%$; mature females normally ovulate within $24 \mathrm{hr}$ (Edwards \& Fowler, 1960) or even within $14 \mathrm{hr}$ (Kaufman \& Whittingham, 1972) of an injection of PMSG.

Oocytes collected between 72 and $120 \mathrm{hr}$ showed an increasing tendency to 
become detached from the surrounding cumulus cells and most of such oocytes which had lost their cumulus cells had large granules in the cytoplasm, indicating that degeneration had started. Most or all of the oocytes collected $120 \mathrm{hr}$ after PMSG treatment had such granules in the cytoplasm.

Table 1. Maturation in vitro of mouse oocytes collected at various times after an injection of PMSG

\begin{tabular}{|c|c|c|c|c|c|c|c|}
\hline \multirow{2}{*}{$\begin{array}{c}\text { Time } \\
\text { after } \\
\text { PMSG } \\
\text { injection } \\
\text { (hr) }\end{array}$} & \multirow[b]{2}{*}{$\begin{array}{l}\text { No. of } \\
\text { animals }\end{array}$} & \multirow[b]{2}{*}{$\begin{array}{l}\text { No. of } \\
\text { oocytes }\end{array}$} & \multicolumn{5}{|c|}{ Condition of oocytes } \\
\hline & & & $\begin{array}{c}\text { Grossly } \\
\text { degenerated }\end{array}$ & $\begin{array}{c}\text { Germinal } \\
\text { vesicle } \dagger\end{array}$ & $\begin{array}{c}\text { Metaphase } \\
I\end{array}$ & $\begin{array}{l}\text { Anaphase } \\
\text { and } \\
\text { telophase }\end{array}$ & $\begin{array}{c}\text { Metaphase } \\
\quad \text { II }\end{array}$ \\
\hline 48 & 4 & 196 & $\begin{array}{c}3.1 \% \\
(6)\end{array}$ & $\begin{array}{l}5 \cdot 1 \% \\
(10)\end{array}$ & $\begin{array}{l}7 \cdot 1 \% \\
(14)\end{array}$ & $\begin{array}{l}2 \cdot 0 \% \\
(4)\end{array}$ & $\begin{array}{l}82 \cdot 7 \% \\
(162)\end{array}$ \\
\hline 60 & 4 & 219 & $\begin{array}{l}5 \cdot 0 \% \\
(11)\end{array}$ & $\begin{array}{c}4 \cdot 1 \% \\
(9)\end{array}$ & $\begin{array}{l}9 \cdot 6 \% \\
(21)\end{array}$ & $\begin{array}{c}1.4 \% \\
(3)\end{array}$ & $\begin{array}{l}79 \cdot 8 \% \\
(175)\end{array}$ \\
\hline 72 & 4 & 184 & $\begin{array}{c}15 \cdot 8 \% \\
(29)\end{array}$ & $\begin{array}{l}7 \cdot 6 \% \\
(14)\end{array}$ & $\begin{array}{c}29 \cdot 3 \% \\
(54)\end{array}$ & $\begin{array}{c}1 \cdot 6 \% \\
(3)\end{array}$ & $\begin{array}{c}45 \cdot 7 \% \\
(84)\end{array}$ \\
\hline 84 & 4 & 243 & $\begin{array}{c}13 \cdot 2 \% \\
(32)\end{array}$ & $\begin{array}{c}13 \cdot 2 \% \\
(32)\end{array}$ & $\begin{array}{c}25 \cdot 1 \% \\
(61)\end{array}$ & - & $\begin{array}{l}48 \cdot 5 \% \\
(118)\end{array}$ \\
\hline 96 & 4 & 181 & $\begin{array}{c}18.8 \% \\
(34)\end{array}$ & $\begin{array}{c}40.9 \% \\
(74)\end{array}$ & $\begin{array}{c}17 \cdot 1 \% \\
(31)\end{array}$ & - & $\begin{array}{c}23 \cdot 2 \% \\
(42)\end{array}$ \\
\hline 108 & 4 & 208 & $\begin{array}{c}19 \cdot 7 \% \\
(41)^{\circ}\end{array}$ & $\begin{array}{l}56.7 \% \\
(118)\end{array}$ & $\begin{array}{l}9 \cdot 6 \% \\
(20)\end{array}$ & $\begin{array}{c}1.0 \% \\
(2)\end{array}$ & $\begin{array}{c}13.0 \% \\
(27)^{\circ}\end{array}$ \\
\hline 120 & 4 & 232 & $\begin{array}{c}34.5 \% \\
(80)\end{array}$ & $\begin{array}{l}65.5 \% \\
(152)\end{array}$ & - & - & - \\
\hline
\end{tabular}

* The stage of nuclear maturation could not be determined.

$\uparrow$ A few oocytes at the condensed chromatin stage were also included.

The results of the experiments are shown in Table 1. The highest percentage $(82.7 \%)$ of oocyte nuclear maturation was obtained when oocytes were collected $48 \mathrm{hr}$ after the injection of PMSG. This percentage is similar to that of $88 \%$ obtained by Donahue (1968) and of $90.7 \%$ by Cross \& Brinster (1970). There was a substantial reduction in the number of oocytes collected after $72 \mathrm{hr}$ which completed nuclear maturation in culture. The number of degenerated oocytes increased only marginally but those arrested at metaphase I increased considerably. There was no increase in the number of oocytes which remained at the germinal vesicle stage. Thus, the reduction in the percentage of oocytes which completed maturation was not due to failure to enter the division cycle but mainly because of the arrest at metaphase I. According to Donahue (1968), there are two stages at which significant numbers of oocytes are arrested other than that which occurs naturally at metaphase II; they are the germinal vesicle $(5$ to $10 \%$ ) and metaphase I $(4 \%)$ stages.

The oocytes cultured $96 \mathrm{hr}$ after the PMSG injection showed a different trend. The reduction in the percentage which completed maturation was mainly because of the failure of a substantial number of oocytes to enter the division cycle rather than to arrest at metaphase I. The percentage of grossly degenerated oocytes had also increased considerably. After $108 \mathrm{hr}$, only $13 \%$ completed the development while those retaining intact germinal vesicles increased from $40.9 \%$ to $56.7 \%$. Even those oocytes which completed nuclear 
maturation did not look normal since all had large granules in the cytoplasm. None of the oocytes collected $120 \mathrm{hr}$ after PMSG treatment proceeded beyond the germinal vesicle stage.

The loss of the developmental potential of the oocytes left in the follicles after PMSG injection is a gradual process which occurs between 72 and $96 \mathrm{hr}$ later. Although no quantitative estimation has been made, it is obvious that cumulus cells must play a very important rôle in this process. Removal of cumulus cells before culture has been shown to reduce the number of oocytes maturing in vitro (Kennedy \& Donahue, 1969; Cross \& Brinster, 1970) although Cross (1973) could not find any effect.

The author is grateful to Professor P. N. Srivastava and Professor A. S. Kapoor for their valuable suggestions.

\section{REFERENGES}

Biggers, J. D., Whittingham, D. G. \& Donahue, R. P. (1967) The pattern of energy metabolism in the mouse oocytes and zygote. Proc. natn. Acad. Sci. U.S.A. 58, 560.

GRoss, P. C. (1973) The rôle of cumulus cells and serum in mouse oocyte maturation in vitro. F. Reprod. Fert. 34, 241.

Gross, P. C. \& Brinster, R. L. (1970) In vitro development of mouse oocytes. Biol. Reprod. 3, 298.

Donahue, R. P. (1968) Maturation of the mouse oocyte in vitro. I. Sequence and timing of nuclear progression. 7. $\exp$. Zool. 169, 237.

EDwARDs, R. G. (1965) Maturation in vitro of mouse, sheep, cow, pig, rhesus monkey and human ovarian oocytes. Nature, Lond. 208, 349.

EDWARDs, R. G. \& FowLER, R. E. (1960) Superovulation treatment of adult mice: their subsequent natural fertility and response to further treatment. F. Endocr. 21, 147.

Edwards, R. G. \& Gatrs, A. H. (1959) Timing of the stages of the maturation divisions, ovulation, fertilization, and the first cleavage of eggs of adult mice. 7. Endocr. 18, 292.

Kauman, M. H. \& Whittingham, D. G. (1972) Viability of mouse oocytes ovulated within 14 hours of an injection of pregnant mares' serum gonadotrophin. $\mathcal{J}$. Reprod. Fert. 28, 465.

KenNedy, J. F. \& Donahue, R. P. (1969) Human oocytes: maturation in chemically defined media. Science, N.Y. 164, 1292.

Merchant, H. \& Ghang, M. G. (1971) An electron microscopic study of mouse eggs matured in vitro and in vivo. Anat. Rec. 171, 21. 